\title{
Zachowania zdrowotne młodzieży w aktualnym kontekście społecznym i ekonomicznym - przegląd wybranych koncepcji
}

\author{
Abstract \\ Health behaviors in adolescence and their socioeconomic context \\ - a review of current knowledge and opinions
}

\begin{abstract}
The aim of the article is to present opinions regarding the nature of associations between socioeconomic determinants and health behaviours in young people. Furthermore, the attempt to assess the potential of mentioned determinants with regard to school-based health promotion was made. The research material, received from the EBSCO databases, made it possible to examine the impact of socioeconomic status (SES), family, school and peer group on adolescents' engagement in healthpromoting and health compromising behaviours.

The findings of the study highlight the important role of SES, school environment, parents' personal example and their relations with children and school in establishing healthy habits. The influence of peers in leading to health compromising behaviours and gender differences in adapting health behaviors were also indicated.
\end{abstract}

\section{Wprowadzenie}

Okres dojrzewania stał się przedmiotem rosnącego zainteresowania wielu międzynarodowych i krajowych organizacji zajmujących się promocją zdrowia, jak również interdyscyplinarnych dyskusji. Instytucje zdrowia publicznego dostrzegły znaczący potencjał tego etapu życia w zakresie tworzenia zdrowego społeczeństwa (Sawyer et al. 2012). W działaniach na rzecz zdrowia i rozwoju młodzieży 
zaczęto również zauważać potencjalne korzyści dla gospodarek narodowych (Resnick et al. 2012; Viner et al. 2012).

Wśród charakterystyk omawianego okresu wywierających wpływ na zdrowie i samopoczucie jednostki w szczególności wymienia się (Sawyer et al. 2012; Hanson, Chen 2007; Haug et al. 2006): większą otwartość na zmianę stylu życia, zauważalne zmiany biologiczne i społeczne (w tym intensywny proces nauczania drogą obserwacji zachowań innych osób), kształtowanie się wielu zachowań zdrowotnych wiążących się z zachorowalnością i umieralnością na różnorodne choroby w przyszłości, znaczną wrażliwość wobec sytuacji stresujących, wysoką aktywność w poszukiwaniu ekscytujących bodźców mogącą prowadzić do zachowań niebezpiecznych dla zdrowia. W związku z szansami i zagrożeniami w budowaniu zdrowia, które stwarza ten etap życia, słuszne wydaje się określanie go jako fundamentu przyszłego zdrowia (Sawyer et al. 2012).

Wśród zachowań związanych ze zdrowiem, a rozwijających się podczas dojrzewania, pojawiają się zarówno działania prozdrowotne (np. zdrowa dieta, aktywność fizyczna), stanowiące niejako funkcję protekcyjną, jak i zachowania ryzykowne. Zauważono, że zachowania z pierwszej grupy wykazują spadek wraz z wiekiem nastolatka, a zachowania ryzykowne tendencję do wzrostu, szczególnie wśród osób w przedziale wiekowym 13-15 lat (Currie et al. 2012). Do zachowań niekorzystnych dla zdrowia, które postrzegane są jako najbardziej problematyczne wśród młodzieży, zalicza się w głównej mierze: palenie papierosów, spożywanie alkoholu i niedozwolonych substancji, ryzykowne zachowania seksualne i nieprawidłową dietę (Jackson et al. 2012). Jednakże działaniem antyzdrowotnym, któremu w obecnych czasach należy poświęcić szczególną uwagę, jest siedzący tryb życia. W zachowaniach sedenteryjnych, obok niewłaściwych nawyków zdrowotnych i statusu socjoekonomicznego, upatruje się głównych przyczyn poważnego problemu, który urósł do poziomu globalnej epidemii - nadwagi i otyłości wśród dzieci i młodzieży (Haugh et al. 2006).

Konsekwencje zachowań szkodliwych dla zdrowia i samopoczucia młodzieży dostrzega m.in. Światowa Organizacja Zdrowia (WHO). Według tego podmiotu omawiane działania, w połączeniu z zauważalnym dla tego okresu spadkiem samooceny zdrowia (szczególnie u dziewcząt), uniemożliwiają młodym ludziom osiągnięcie pełni zdrowia (Currie et al. 2012). Niewątpliwie skutki niektórych z tych zachowań pogłębia fakt, że mają one tendencję do współwystępowania ${ }^{1}$ (Jackson et al. 2012). Pomimo zagrożeń zdrowotnych, na które są narażone osoby w okresie dojrzewania, WHO postrzega go jako „wiek możliwości dla przedsięwzięć mających na celu niwelowanie nierówności w zakresie zdrowia" (Currie et al. 2012).

Analizując zdrowie młodych ludzi, nie sposób pominąć faktu, że jednymi z głównych uwarunkowań przesądzających o tym, czy zaangażują się oni w określone działania związane ze zdrowiem, są czynniki o charakterze społecznym i ekonomicznym. Wyróżnia się dwa rodzaje tych czynników: strukturalne (dalsze)

1 Wśród tych zachowań autorzy wyszczególniają: palenie papierosów, spożywanie alkoholu i stosowanie niedozwolonych substancji. 
i proksymalne (bliższe). Do pierwszych zalicza się m.in. dochód narodowy, system polityczny i edukacji, poziom bezrobocia w kraju. Natomiast w grupie czynników proksymalnych można wymienić m.in. grupę rówieśniczą, rodzinę i SES (Viner et al. 2012; Currie et al. 2004).

Co istotne pod kątem tworzenia efektywnych programów promocji zdrowia dla młodzieży, oddziaływania pomiędzy zmiennymi o charakterze społecznym i ekonomicznym a zachowaniami zdrowotnymi nie zachodzą w stałych warunkach. Warto odnotować, że otoczenie, w którym występują omawiane relacje, uległo na przestrzeni ostatnich lat bardzo dynamicznym zmianom, wywierającym znaczący i bezpośredni wpływ na zdrowie młodych ludzi. $Z$ omawianych przeobrażeń na wyróżnienie zasługują: globalizacja wraz z idącą w ślad za nią szybką wymianą norm kulturowych, gwałtowna urbanizacja, spadek roli rodziny w wychowaniu dzieci, wzrost oczekiwań wobec młodych ludzi (w sferze edukacyjnej i zawodowej), dostęp do informacji z całego świata za pośrednictwem nowoczesnych mediów oraz agresywny marketing koncernów tytoniowych i alkoholowych skierowany głównie do młodych osób (Resnick et al. 2012; Sawyer et al. 2012).

Celem niniejszego opracowania jest przedstawienie wybranych poglądów odnośnie charakteru związków zachodzących pomiędzy czynnikami społeczno-ekonomicznymi a zachowaniami zdrowotnymi młodych ludzi. Podjęto w nim także próbę wskazania istotnego potencjału powyższych determinantów w zakresie kształtowania postaw prozdrowotnych osób na tym etapie życia w ramach szkolnej rzeczywistości. Wydało się to zagadnieniem istotnym w obliczu wzrostu występowania zachowań ryzykownych wśród młodzieży (Lazzeri et al. 2014; Phongsavan et al. 2005), rosnącej roli mediów i marketingu, spadku samooceny zdrowia (Currie et al. 2012) oraz możliwości, które stwarza wiek młodzieńczy w zakresie jego budowania (Sawyer et al. 2012).

\section{Materiał i metoda}

W pracy zastosowano metodę analizy publikacji zagranicznych poruszających tematykę wpływu czynników społeczno-ekonomicznych na zachowania związane ze zdrowiem ludzi młodych. Otrzymano je w wyniku przeszukania baz elektronicznych EBSCO. Do ostatecznej analizy wybrano 14 pełnych tekstów. Jednym z nich jest raport z międzynarodowego badania HBSC 2009/2010 oceniającego m.in. zdrowie, dobrostan oraz zachowania zdrowotne młodzieży. O randze przytoczonej publikacji i zarazem konieczności uwzględnienia jej w analizie, poza zakresem tematycznym badania, zadecydowała skala przeprowadzonego badania: 200000 dzieci i młodzieży obu płci (grupy wiekowe 11, 13 i 15 lat) z 39 krajów Europy i Ameryki Północnej (Currie et al. 2012).

2 Rozwinięcie skrótu HBSC: Health Behaviour in School-aged Children (zachowania zdrowotne dzieci w wieku szkolnym). 


\section{Wyniki}

W niniejszej pracy analizie poddano publikacje podejmujące tematykę oddziaływania wybranych determinantów społeczno-ekonomicznych na zachowania zdrowotne osób w okresie dojrzewania. Wśród nich było 7 pełnych tekstów przedstawiających wyniki z pojedynczych badań, 4 raporty dostarczające aktualnych danych dotyczących zdrowia nastolatków w ujęciu międzynarodowym, 2 przeglądy publikacji odnośnie wpływu statusu socjoekonomicznego na zachowania zdrowotne oraz zestawienie programów interwencyjnych ukierunkowanych na zmniejszenie różnorodnych zachowań problemowych. W przypadku pierwszej grupy publikacji, dostarczających empirycznych wyników z konkretnych badań, liczebność próby badawczej wahała się w przedziale 475-17 766 osób, a wiek uczestników badań wynosił 10-21 lat. Dane prezentowane w światowych raportach dotyczyły zarówno młodzieży, jak i młodych dorosłych, stąd w ich przypadku przedział wiekowy był nieco wyższy - od 10 do 24 lat. Z kolei autorzy przeglądów literatury przedmiotu za wiek osoby w okresie dojrzewania przyjmowali na ogół wiek 10-21 lat, z wyjątkiem jednej publikacji, która poza młodzieżą uwzględniała również młodych dorosłych i w związku z tym dotyczyła osób w wieku 11-25 lat.

Wśród zachowań zdrowotnych młodzieży pojawiły się działania sprzyjające zdrowiu, jak również te dla niego szkodliwe. Pierwsza grupa zachowań obejmowała: aktywność fizyczną i zdrową dietę (włączając konsumpcję owoców i warzyw oraz dostarczanie dziennej dawki witamin). W drugiej natomiast wystąpiły: palenie tytoniu, spożywanie alkoholu (w tym upijanie się) i niedozwolonych substancji, niezdrowa dieta (nieregularne spożywanie śniadań oraz konsumpcja produktów bogatych w cukry i tłuszcz), siedzący tryb życia (zachowania sedenteryjne), ryzykowne zachowania seksualne, kontuzjogenność, skłonność do podejmowania zachowań ryzykownych (np. udziału w bójkach). Niektórzy autorzy pierwsze trzy zachowania ujmowali łącznie jako „stosowanie/nadużywanie substancji psychoaktywnych” (Jackson et al. 2012; Farmer, Hanratty 2012; Viner et al. 2012; Brooks et al. 2012).

Jak wskazuje analiza zebranego materiału, pomiędzy wyszczególnionymi czynnikami społeczno-ekonomicznymi a zachowaniami zdrowotnymi młodzieży (zarówno tymi wywierającymi pozytywne, jak i negatywne rezultaty w zakresie zdrowia) występują bezpośrednie relacje. Uwarunkowaniem społeczno-ekonomicznym najczęściej wymienianym w ujętych publikacjach był status socjoekonomiczny. Wśród miar, według których szacowano SES, znalazły się: skala zasobów materialnych rodziny (Lazzeri et al. 2014), uprawnienie do pobierania darmowych posiłków (Farmer, Hanratty 2012), profesja ojca (Thibault et al. 2009), wykształcenie rodziców (Ferreira et al. 2006), status zawodowy rodziców (Haug et al. 2006), pozycja społeczna rodzica o wyższym stanowisku (Raudsepp, Viira 2000), wykształcenie matki (Gordon-Larsen et al. 2000) i dochód rodziny (Ferreira et al. 2006; Haug et al. 2006; Raudsepp, Viira 2000; Gordon-Larsen et al. 2000).

Środowisko szkolne, które było drugą ze zmiennych determinujących zachowania zdrowotne, określano przez: stosunek do szkoły, wsparcie rówieśnicze, osiągnięcia szkolne (Lazzeri et al. 2014), postrzeganie szkoły jako wspierającego środowiska (Currie et al. 2012), relacje rodziców i dzieci ze szkołą (Viner et al. 2012) oraz poczucie przynależności do szkolnej społeczności (Brooks et al. 2012). 
Kolejnym z czynników podlegających analizie pod kątem siły i kierunku oddziaływania na zdrowie młodych ludzi była grupa rówieśnicza. Określono ją na podstawie: liczby kolegów i koleżanek, częstotliwości pozaszkolnych kontaktów z rówieśnikami (Lazzeri et al. 2014) oraz liczby bliskich przyjaciół i relacji z przyjaciółmi, włączając możliwość dzielenia się w rozmowach problemami (Farmer, Hanratty 2012). Zwrócono także uwagę na gwałtowny wzrost siły oddziaływania grupy rówieśniczej wynikający z globalnej popularności technologii komunikacyjno-informacyjnych (Sawyer et al. 2012; Viner et al. 2012).

W przypadku rodziny i bliskiego otoczenia miarami wyrażającymi zmienną były: wsparcie ze strony rodziców i przyjaciół (Cazuza de Farias Júnior et al. 2014), komunikacja z rodzicami (Farmer, Hanratty 2012), relacje z rodziną i stopień kontroli rodzicielskiej (Viner et al. 2012), wpływ rodziców na organizację czasu wolnego (Brooks et al. 2012), nadwaga/otyłość i aktywność fizyczna rodziców (Thibault et al. 2009), aktywność fizyczna obojga rodziców i najlepszego przyjaciela (Raudsepp, Viira 2000). Jedynie w jednej z analizowanych publikacji podjęto próbę oceny wpływu wsparcia społecznego ujmowanego w kontekście poczucia przynależności do zbiorowości (Brooks et al. 2012).

Przeglądu uwarunkowań społeczno-ekonomicznych i opisu kierunku ich oddziaływania na poszczególne zachowania zdrowotne dokonano w tabeli 1.

Tabela 1. Wybrane czynniki społeczno-ekonomiczne i ich wpływ na zachowania zdrowotne młodzieży

\begin{tabular}{|c|c|c|c|c|}
\hline Publikacja & Badanie & $\begin{array}{c}\text { Zachowania } \\
\text { zdrowotne }\end{array}$ & $\begin{array}{c}\text { Czynnik } \\
\text { determinujący }\end{array}$ & $\begin{array}{c}\text { Kierunek } \\
\text { oddziaływania }\end{array}$ \\
\hline \multirow[t]{3}{*}{ Lazzeri et al. 2014} & \multirow[t]{3}{*}{\begin{tabular}{|l|} 
Badanie prze- \\
krojowe HBSC \\
$2009 / 10$ (Włochy), \\
$n=3291$, ucznio- \\
wie obu płci, grupy \\
wiekowe: 11, \\
13,15
\end{tabular}} & \multirow[t]{3}{*}{$\begin{array}{l}\text { Palenie tytoniu, } \\
\text { spożywanie alko- } \\
\text { holu, nieregular- } \\
\text { ne spożywanie } \\
\text { śniadań, siedzący } \\
\text { tryb życia }\end{array}$} & $\begin{array}{l}\text { Środowisko } \\
\text { szkolne (stosunek } \\
\text { do szkoły, wspar- } \\
\text { cie rówieśników, } \\
\text { presja szkolna, } \\
\text { osiągnięcia } \\
\text { szkolne) }\end{array}$ & \multirow{2}{*}{$\begin{array}{l}\text { Negatywne po- } \\
\text { strzeganie szkoły } \\
\text { i grupa rówie- } \\
\text { śnicza wykazały } \\
\text { powiązanie ze } \\
\text { spożywaniem } \\
\text { niedozwolonych } \\
\text { substancji (alko- } \\
\text { hol, tytoń) oraz } \\
\text { siedzącym trybem } \\
\text { życia }\end{array}$} \\
\hline & & & $\begin{array}{l}\text { Grupa rówieśnicza } \\
\text { (liczba kolegów } \\
\text { i koleżanek, kon- } \\
\text { takty z rówieśnika- } \\
\text { mi poza szkołą) }\end{array}$ & \\
\hline & & & $\begin{array}{l}\text { SES (mierzony } \\
\text { z zastosowaniem } \\
\text { skali FAS }{ }^{a} \text { ) }\end{array}$ & $\begin{array}{l}\text { Nikły wpływ na } \\
\text { analizowane za- } \\
\text { chowania ryzykow- } \\
\text { ne w porównaniu } \\
\text { z ww. czynnikami }\end{array}$ \\
\hline $\begin{array}{l}\text { Cazuza de Farias } \\
\text { Júnior et al. } 2014\end{array}$ & \begin{tabular}{|l|} 
Część badania \\
Physical activity \\
levels and factors \\
among high school \\
students in the city \\
of João Pessoab" \\
(Brazylia, 2009), \\
$n=2755$ osoby obu \\
płci, wiek $14-18$
\end{tabular} & Aktywność fizyczna & $\begin{array}{l}\text { Wsparcie społecz- } \\
\text { ne ze strony rodzi- } \\
\text { ców i przyjaciół }\end{array}$ & $\begin{array}{l}\text { Wykryto istotną } \\
\text { statystycznie do- } \\
\text { datnią zależność } \\
\text { pomiędzy AF } \\
\text { a wsparciem spo- } \\
\text { łecznym ze strony } \\
\text { obu grup }\end{array}$ \\
\hline
\end{tabular}


Tabela 1 (cd.)

\begin{tabular}{|c|c|c|c|c|}
\hline Publikacja & Badanie & $\begin{array}{c}\text { Zachowania } \\
\text { zdrowotne }\end{array}$ & $\begin{array}{c}\text { Czynnik } \\
\text { determinujący }\end{array}$ & $\begin{array}{c}\text { Kierunek } \\
\text { oddziaływania }\end{array}$ \\
\hline \multirow[t]{2}{*}{$\begin{array}{l}\text { Currie et al. } 2012 \\
\text { (WHO Regional } \\
\text { Office for Europe) }\end{array}$} & \multirow[t]{2}{*}{$\begin{array}{l}\text { Raport z badania } \\
\text { HBSC 2009/2010, } \\
39 \text { państw, } \\
\mathrm{n}=200000 \\
\text { osoby obu płci, } \\
\text { grupy wiekowe: } \\
11,13,15\end{array}$} & \multirow[t]{2}{*}{$\begin{array}{l}\text { Palenie tytoniu, } \\
\text { spożywanie alko- } \\
\text { holu, niezdrowa } \\
\text { dieta, siedzący } \\
\text { tryb życia }\end{array}$} & $\begin{array}{l}\text { Środowisko } \\
\text { szkolne }\end{array}$ & $\begin{array}{l}\text { Zaobserwowano, } \\
\text { że osoby postrze- } \\
\text { gające szkołe } \\
\text { jako środowisko } \\
\text { wspierające były } \\
\text { bardziej skłonne } \\
\text { do podejmowania } \\
\text { zachowań proz- } \\
\text { drowotnych, mniej } \\
\text { skłonne do palenia } \\
\text { papierosów } \\
\text { i zgłaszały mniej } \\
\text { skarg dotyczących } \\
\text { zdrowia }\end{array}$ \\
\hline & & & SES & $\begin{array}{l}\text { Wysoki SES wią- } \\
\text { zał się z większą } \\
\text { skłonnością } \\
\text { do zachowań } \\
\text { prozdrowotnych } \\
\text { (w tym spożywania } \\
\text { owoców i śniadań) } \\
\text { i niższą skłonno- } \\
\text { ścią do zachowań } \\
\text { sedenteryjnych; } \\
\text { niski SES był zwią- } \\
\text { zany z większą } \\
\text { częstotliwością } \\
\text { występowania } \\
\text { nadwagi i otyłości } \\
\text { (Europa Zachod- } \\
\text { nia, Ameryka } \\
\text { Północna) }\end{array}$ \\
\hline $\begin{array}{l}\text { Jackson et al. } \\
2012\end{array}$ & $\begin{array}{l}\text { Przegląd pro- } \\
\text { gramów inter- } \\
\text { wencyjnych dla } \\
\text { młodzieży i mło- } \\
\text { dych dorosłych } \\
\text { ukierunkowanych } \\
\text { na zmniejszenie } \\
\text { określonych } \\
\text { zachowań nie- } \\
\text { korzystnych dla } \\
\text { zdrowia, wiek } \\
\text { 11-25 }\end{array}$ & $\begin{array}{l}\text { Palenie tytoniu, } \\
\text { spożywanie alko- } \\
\text { holu i niedozwo- } \\
\text { lonych substancji, } \\
\text { ryzykowne zacho- } \\
\text { wania seksualne }\end{array}$ & SES & $\begin{array}{l}\text { Niski SES wykazał } \\
\text { powiązanie z niski- } \\
\text { mi osiągnięciami } \\
\text { edukacyjnymi } \\
\text { i w konsekwencji } \\
\text { wyższym ryzykiem } \\
\text { wykluczenia spo- } \\
\text { łecznego i większą } \\
\text { skłonnością do } \\
\text { podejmowania } \\
\text { zachowań szkodli- } \\
\text { wych dla zdrowia }\end{array}$ \\
\hline
\end{tabular}


Tabela 1 (cd.)

\begin{tabular}{|c|c|c|c|c|}
\hline Publikacja & Badanie & $\begin{array}{c}\text { Zachowania } \\
\text { zdrowotne }\end{array}$ & $\begin{array}{c}\text { Czynnik } \\
\text { determinujący }\end{array}$ & $\begin{array}{c}\text { Kierunek } \\
\text { oddziaływania }\end{array}$ \\
\hline \multirow[t]{3}{*}{$\begin{array}{l}\text { Farmer, Hanratty } \\
2012\end{array}$} & \multirow[t]{3}{*}{$\begin{array}{l}\text { Badanie prze- } \\
\text { krojowe Tellus4 } \\
\text { (Anglia, 2009), } \\
\text { n = 3903, dzieci } \\
\text { szkolne obu płci, } \\
\text { wiek 10-15 }\end{array}$} & \multirow[t]{3}{*}{$\begin{array}{l}\text { Palenie tytoniu, } \\
\text { spożywanie alko- } \\
\text { holu i niedozwolo- } \\
\text { nych substancji }\end{array}$} & $\begin{array}{l}\text { Rodzina (komuni- } \\
\text { kacja z rodzicami) }\end{array}$ & $\begin{array}{l}\text { Osoby mające } \\
\text { lepszą komuni- } \\
\text { kację z rodzicami } \\
\text { wykazywały niższą } \\
\text { skłonność do } \\
\text { regularnego stoso- } \\
\text { wania szkodliwych } \\
\text { substancji (głównie } \\
\text { palenia) }\end{array}$ \\
\hline & & & $\begin{array}{l}\text { Grupa rówieśnicza } \\
\text { (liczba bliskich } \\
\text { przyjaciół, relacje } \\
\text { z przyjaciółmi) }\end{array}$ & $\begin{array}{l}\text { Odnotowano } \\
\text { związek pomiędzy } \\
\text { silnymi relacjami } \\
\text { z przyjaciółmi } \\
\text { i większym praw- } \\
\text { dopodobieństwem } \\
\text { stosowania szko- } \\
\text { dliwych substancji }\end{array}$ \\
\hline & & & $\begin{array}{l}\text { SES (niski dochód } \\
\text { gospodarstwa do- } \\
\text { mowego wyrażony } \\
\text { w uprawnieniu do } \\
\text { pobierania dar- } \\
\text { mowych posiłków } \\
\text { w szkole) }\end{array}$ & $\begin{array}{l}\text { Zaobserwowano } \\
\text { związek między } \\
\text { niskim SES } \\
\text { i większą często- } \\
\text { tliwością palenia } \\
\text { i stosowania } \\
\text { niedozwolonych } \\
\text { substancji }\end{array}$ \\
\hline \multirow[t]{2}{*}{ Sawyer et al. 2012} & \multirow[t]{2}{*}{$\begin{array}{l}\text { Raport „Adoles- } \\
\text { cence: a founda- } \\
\text { tion for future } \\
\text { health” - prze- } \\
\text { gląd danych mię- } \\
\text { dzynarodowych } \\
\text { organizacji (m.in. } \\
\text { WHO, WB, } \\
\text { UNESCO i United } \\
\text { Nations) }\end{array}$} & \multirow[t]{2}{*}{$\begin{array}{l}\text { Stosowanie szko- } \\
\text { dliwych substancji, } \\
\text { siedzący tryb } \\
\text { życia, otyłość, } \\
\text { kontuzjogenność, } \\
\text { skłonność do } \\
\text { podejmowania } \\
\text { zachowań ryzy- } \\
\text { kownych }\end{array}$} & $\begin{array}{l}\text { Środowisko } \\
\text { szkolne }\end{array}$ & $\begin{array}{l}\text { Wskazano, że } \\
\text { szkoła jest środo- } \\
\text { wiskiem wspierają- } \\
\text { cym zdrowie i kon- } \\
\text { trolę emocjonalną } \\
\text { oraz na potencjał } \\
\text { interwencji szkol- } \\
\text { nych w zakresie } \\
\text { zmniejszania } \\
\text { stosowania sub- } \\
\text { stancji szkodliwych } \\
\text { dla zdrowia }\end{array}$ \\
\hline & & & $\begin{array}{l}\text { Grupa rówieśnicza } \\
\text { (wpływ wzmocnio- } \\
\text { ny globalizacją } \\
\text { i wzrostem znacze- } \\
\text { nia mediów spo- } \\
\text { łecznościowych) }\end{array}$ & $\begin{array}{l}\text { Wysoki wpływ } \\
\text { rówieśników } \\
\text { przekładał się na } \\
\text { eksperymentowa- } \\
\text { nie ze szkodliwymi } \\
\text { substancjami }\end{array}$ \\
\hline
\end{tabular}


Tabela 1 (cd.)

\begin{tabular}{|c|c|c|c|c|}
\hline Publikacja & Badanie & $\begin{array}{l}\text { Zachowania } \\
\text { zdrowotne }\end{array}$ & $\begin{array}{c}\text { Czynnik } \\
\text { determinujący }\end{array}$ & $\begin{array}{c}\text { Kierunek } \\
\text { oddziaływania }\end{array}$ \\
\hline \multirow[t]{4}{*}{ Viner et al. 2012} & \multirow[t]{4}{*}{$\begin{array}{l}\text { Raport „Adoles- } \\
\text { cence and the } \\
\text { social determi- } \\
\text { nants of health” } \\
\text { - przegląd danych } \\
\text { międzynarodo- } \\
\text { wych organizacji } \\
\text { (m.in. WHO, WB, } \\
\text { UNESCO) oraz } \\
\text { analiz na pod- } \\
\text { stawie danych } \\
\text { United Nations }\end{array}$} & \multirow[t]{4}{*}{$\begin{array}{l}\text { Zachowania ry- } \\
\text { zykowne (m.in. } \\
\text { stosowanie szko- } \\
\text { dliwych substancji, } \\
\text { niebezpieczne } \\
\text { zachowania sek- } \\
\text { sualne) }\end{array}$} & $\begin{array}{l}\text { Rodzina (relacje } \\
\text { w rodzinie, kontro- } \\
\text { la rodzicielska) }\end{array}$ & $\begin{array}{l}\text { Odnotowano } \\
\text { związek między: } \\
\text { dobrymi relacjami } \\
\text { z rodziną i mniej- } \\
\text { szą skłonnością do } \\
\text { stosowania szko- } \\
\text { dliwych substancji, } \\
\text { wysoką kontrolą } \\
\text { rodzicielską } \\
\text { i mniejszą skłonno- } \\
\text { ścią do podejmo- } \\
\text { wania zachowań } \\
\text { ryzykownych (sek- } \\
\text { sualnych, stoso- } \\
\text { wania szkodliwych } \\
\text { substancji, prze- } \\
\text { mocy), negatywny- } \\
\text { mi zachowaniami } \\
\text { zdrowotnymi ro- } \\
\text { dziców (papierosy, } \\
\text { alkohol) i większym } \\
\text { ryzykiem podej- } \\
\text { mowania ich przez } \\
\text { nastoletnie dzieci }\end{array}$ \\
\hline & & & $\begin{array}{l}\text { Środowisko } \\
\text { szkolne (relacje) }\end{array}$ & $\begin{array}{l}\text { Silne relacje } \\
\text { uczniów i rodzi- } \\
\text { ców ze szkołą } \\
\text { przekładały się } \\
\text { na pozytywne } \\
\text { skutki zdrowotne } \\
\text { (kraje o umiarko- } \\
\text { wanym i niskim } \\
\text { dochodzie); relacje } \\
\text { w szkole pełniły } \\
\text { funkcję ochronną } \\
\text { przed zachowania- } \\
\text { mi ryzykownymi }\end{array}$ \\
\hline & & & Grupa rówieśnicza & $\begin{array}{l}\text { Wykazano dwu- } \\
\text { kierunkowość } \\
\text { wpływu czynników } \\
\text { związanych z gru- } \\
\text { pą rówieśniczą } \\
\text { w zakresie podej- } \\
\text { mowania zacho- } \\
\text { wań ryzykownych } \\
\text { (w zależności od } \\
\text { charakteru grupy) }\end{array}$ \\
\hline & & & SES & $\begin{array}{l}\text { Niski SES wykazał } \\
\text { powiązanie z wyż- } \\
\text { szą skłonnością } \\
\text { do podejmowania } \\
\text { zachowań ryzy- } \\
\text { kownych }\end{array}$ \\
\hline
\end{tabular}


Tabela 1 (cd.)

\begin{tabular}{|c|c|c|c|c|}
\hline Publikacja & Badanie & $\begin{array}{c}\text { Zachowania } \\
\text { zdrowotne }\end{array}$ & $\begin{array}{c}\text { Czynnik } \\
\text { determinujący }\end{array}$ & $\begin{array}{c}\text { Kierunek } \\
\text { oddziaływania }\end{array}$ \\
\hline \multirow[t]{3}{*}{ Brooks et al. 2012} & \multirow[t]{3}{*}{$\begin{array}{l}\text { Badanie HBSC } \\
2009 / 10 \text { (Anglia), } \\
n=1255 \\
\text { uczniowie obu } \\
\text { płci, wiek } 15\end{array}$} & \multirow[t]{3}{*}{$\begin{array}{l}\text { Palenie tytoniu } \\
\text { i marihuany, spo- } \\
\text { żywanie alkoholu } \\
\text { i częstość upijania } \\
\text { się, ryzykowne } \\
\text { zachowania sek- } \\
\text { sualne }\end{array}$} & Rodzina & $\begin{array}{l}\text { Większy udział } \\
\text { rodziców w or- } \\
\text { ganizowaniu } \\
\text { czasu wolnego był } \\
\text { związany z niższą } \\
\text { skłonnością do } \\
\text { podejmowania } \\
\text { zachowań szko- } \\
\text { dzących zdrowiu }\end{array}$ \\
\hline & & & $\begin{array}{l}\text { Środowisko } \\
\text { szkolne }\end{array}$ & \multirow{2}{*}{$\begin{array}{l}\text { Osoby z wyso- } \\
\text { kim poczuciem } \\
\text { przynależności } \\
\text { do każdej z tych } \\
\text { sfer wykazywały } \\
\text { niższą skłonność } \\
\text { do angażowania } \\
\text { się w zachowania } \\
\text { ryzykowne }\end{array}$} \\
\hline & & & Społeczność & \\
\hline \multirow[t]{2}{*}{$\begin{array}{l}\text { Thibault et al. } \\
2009\end{array}$} & \multirow[t]{2}{*}{$\begin{array}{l}\text { Badanie przekrojo- } \\
\text { we (Francja 2004- } \\
2005), n=2385 \\
\text { uczniowie obu płci, } \\
\text { wiek } 11-18\end{array}$} & \multirow[t]{2}{*}{$\begin{array}{l}\text { Aktywność fizycz- } \\
\text { na, siedzący tryb } \\
\text { życia (w kontek- } \\
\text { ście problemu } \\
\text { nadwagi i otyłości) }\end{array}$} & $\begin{array}{l}\text { Rodzina (otyłość } \\
\text { i aktywność fizycz- } \\
\text { na rodziców) }\end{array}$ & $\begin{array}{l}\text { Zaobserwowano } \\
\text { związki pomiędzy: } \\
\text { nadwagą rodziców } \\
\text { i dzieci, AF rodzi- } \\
\text { ców i mniejszą } \\
\text { częstością zajęć } \\
\text { sedenteryjnych } \\
\text { u dzieci }\end{array}$ \\
\hline & & & $\begin{array}{l}\text { SES (profesja } \\
\text { ojca) }\end{array}$ & $\begin{array}{l}\text { Niski SES zna- } \\
\text { cząco zwiększał } \\
\text { ryzyko otyłości } \\
\text { u młodszych osób, } \\
\text { u młodzieży z ro- } \\
\text { dzin o wyższym } \\
\text { SES średnia ilość } \\
\text { czasu poświęcona } \\
\text { na AF była znaczą- } \\
\text { co wyższa, a czas } \\
\text { poświęcany na } \\
\text { zachowania se- } \\
\text { denteryjne znacz- } \\
\text { nie niższy }\end{array}$ \\
\hline $\begin{array}{l}\text { Hanson, Chen } \\
2007\end{array}$ & $\begin{array}{l}\text { Przegląd literatury } \\
\text { nt. wpływu SES } \\
\text { na zachowania } \\
\text { zdrowotne osób } \\
\text { w okresie doj- } \\
\text { rzewania, grupy } \\
\text { wiekowe: } 10-14 \\
\text { (okres nastoletni } \\
\text { wczesny), 15-21 } \\
\text { (okres nastoletni } \\
\text { późny) }\end{array}$ & $\begin{array}{l}\text { Palenie tytoniu } \\
\text { i marihuany, spo- } \\
\text { żywanie alkoholu, } \\
\text { dieta, aktywność } \\
\text { fizyczna }\end{array}$ & SES & $\begin{array}{l}\text { Niski SES wyka- } \\
\text { zał powiązanie } \\
\text { z niższą AF i gor- } \\
\text { szymi nawykami } \\
\text { żywieniowymi } \\
\text { oraz z wyższą } \\
\text { częstością palenia } \\
\text { papierosów }\end{array}$ \\
\hline
\end{tabular}


Tabela 1 (cd.)

\begin{tabular}{|c|c|c|c|c|}
\hline Publikacja & Badanie & $\begin{array}{l}\text { Zachowania } \\
\text { zdrowotne }\end{array}$ & $\begin{array}{c}\text { Czynnik } \\
\text { determinujący }\end{array}$ & $\begin{array}{c}\text { Kierunek } \\
\text { oddziaływania }\end{array}$ \\
\hline Ferreira et al. 2006 & $\begin{array}{l}\text { Przegląd literatury } \\
\text { z } 25 \text { lat nt. wpływu } \\
\text { determinantów } \\
\text { środowiskowych } \\
\text { na aktywność fi- } \\
\text { zyczną młodzieży, } \\
\text { wiek 13-18 }\end{array}$ & $\begin{array}{l}\text { Aktywność fizycz- } \\
\text { na (w kontekście } \\
\text { rosnącego proble- } \\
\text { mu otyłości) }\end{array}$ & $\begin{array}{l}\text { SES (poziom } \\
\text { wykształcenia } \\
\text { rodziców, dochód } \\
\text { rodziny) }\end{array}$ & $\begin{array}{l}\text { Zarówno wyższe } \\
\text { wykształcenie } \\
\text { matki, jak i wyższy } \\
\text { dochód były zwią- } \\
\text { zane z wyższą } \\
\text { AF (zależności } \\
\text { wykazano dopiero } \\
\text { w analizie wpływu } \\
\text { pojedynczych miar } \\
\text { SES na AF) }\end{array}$ \\
\hline $\begin{array}{l}\text { Haug et al. } 2006 \\
\text { (WHO Regional } \\
\text { Office for Europe) }\end{array}$ & $\begin{array}{l}\text { Publikacja z WHO/ } \\
\text { HBSC Forum } 2006 \\
\text { (nawiązanie do } \\
\text { wyników badania } \\
\text { HBSC } 2001 / 2002 \text {, } \\
35 \text { państw, ucznio- } \\
\text { wie obu płci, grupy } \\
\text { wiekowe: } 11,13 \text {, } \\
\text { 15) }\end{array}$ & $\begin{array}{l}\text { Aktywność fizycz- } \\
\text { na, siedzący tryb } \\
\text { życia, nawyki ży- } \\
\text { wieniowe (w kon- } \\
\text { tekście problemu } \\
\text { nadwagi i otyłości) }\end{array}$ & $\begin{array}{l}\text { SES (dochód ro- } \\
\text { dziny, status zawo- } \\
\text { dowy rodziców) }\end{array}$ & $\begin{array}{l}\text { Wysoki SES wy- } \\
\text { kazał powiązanie } \\
\text { z większym spoży- } \\
\text { ciem owoców, niski } \\
\text { SES wpływał na } \\
\text { większą częstość } \\
\text { oglądania TV; } \\
\text { w krajach Euro- } \\
\text { py Zachodniej, } \\
\text { Północnej i Połu- } \\
\text { dniowej wyższy } \\
\text { SES przekłada } \\
\text { się na mniejsze } \\
\text { spożycie słodkich } \\
\text { napojów i mniej- } \\
\text { szą częstość } \\
\text { występowania } \\
\text { otyłości (w krajach } \\
\text { Europy Środkowo- } \\
\text {-Wschodniej odno- } \\
\text { towano zależność } \\
\text { odwrotną) }\end{array}$ \\
\hline \multirow[t]{2}{*}{$\begin{array}{l}\text { Raudsepp, Viira } \\
2000\end{array}$} & \multirow[t]{2}{*}{$\begin{array}{l}\text { (Estonia 1997), } \\
\mathrm{n}=475, \text { osoby } \\
\text { obu płci, wiek } \\
\text { 13-15, mieszkań- } \\
\text { cy miasta Tartu }\end{array}$} & \multirow[t]{2}{*}{$\begin{array}{l}\text { Aktywność } \\
\text { fizyczna }\end{array}$} & $\begin{array}{l}\text { Najbliższe otocze- } \\
\text { nie (rodzice, star- } \\
\text { sze rodzeństwo, } \\
\text { przyjaciel) }\end{array}$ & $\begin{array}{l}\text { Wykazano związki } \\
\text { pomiędzy: AF ojca } \\
\text { i przyjaciela a AF } \\
\text { młodzieży (obie } \\
\text { płcie), AF matki } \\
\text { a bardzo wysoką } \\
\text { AF badanych } \\
\text { (dziewczęta) }\end{array}$ \\
\hline & & & $\begin{array}{l}\text { SES (pozycja } \\
\text { społeczna rodzica } \\
\text { o wyższym sta- } \\
\text { nowisku, dochód } \\
\text { miesięczny na } \\
\text { jednego członka } \\
\text { rodziny) }\end{array}$ & $\begin{array}{l}\text { Wykazano zależ- } \\
\text { ność odwrotnie } \\
\text { proporcjonalną po- } \\
\text { między dochodem } \\
\text { rodziny a AF oraz } \\
\text { zależność wprost } \\
\text { proporcjonalną } \\
\text { pomiędzy klasą } \\
\text { społeczną a AF } \\
\text { (kontekst społecz- } \\
\text { no-ekonomiczny } \\
\text { kraju) }\end{array}$ \\
\hline
\end{tabular}


Tabela 1 (cd.)

\begin{tabular}{|l|l|l|l|l|}
\hline \multicolumn{1}{|c|}{ Publikacja } & \multicolumn{1}{|c|}{ Badanie } & \multicolumn{1}{c|}{$\begin{array}{c}\text { Zachowania } \\
\text { zdrowotne }\end{array}$} & $\begin{array}{c}\text { Czynnik } \\
\text { determinujący }\end{array}$ & \multicolumn{1}{c|}{$\begin{array}{c}\text { Kierunek } \\
\text { oddziaływania }\end{array}$} \\
\hline $\begin{array}{l}\text { Gordon-Larsen } \\
\text { et al. 2000 }\end{array}$ & $\begin{array}{l}\text { Badanie National } \\
\text { Longitudinal Study } \\
\text { of Adolescent } \\
\text { Health „Add } \\
\text { Health” (USA } \\
\text { 1996), n=177 66, } \\
\text { uczniowe obu płci, } \\
\text { wiek 11-21 }\end{array}$ & $\begin{array}{l}\text { Aktywność fizycz- } \\
\text { na, siedzący tryb } \\
\text { życia (w kontek- } \\
\text { ście problemu } \\
\text { nadwagi) }\end{array}$ & $\begin{array}{l}\text { SES (wykształce- } \\
\text { nie matki, dochód } \\
\text { rodziny) }\end{array}$ & $\begin{array}{l}\text { Bardzo wysoki } \\
\text { SES był związany } \\
\text { z niższą często- } \\
\text { ścią występowania } \\
\text { zachowań seden- } \\
\text { teryjnych oraz } \\
\text { wyższą częstością } \\
\text { podejmowania } \\
\text { umiarkowanej } \\
\text { i intensywnej AF }\end{array}$ \\
\hline
\end{tabular}

a Źródło: FAS (Family Affluence Scale - skala zasobów materialnych rodziny). aFAS (Family Affluence Scale - skala zasobów materialnych rodziny).

b Tłum. „Poziom i czynniki aktywności fizycznej u uczniów szkół średnich w mieście João Pessoa".

SES - status socjoekonomiczny (rodziców), AF - aktywność fizyczna, WB - Bank Światowy (The World Bank), UNESCO - Organizacja Narodów Zjednoczonych do Spraw Oświaty, Nauki i Kultury (United Nations Educational, Scientific and Cultural Organization), United Nations - Narody Zjednoczone

\section{Dyskusja}

W pracy podjęto próbę rozpoznania kierunku oddziaływania wybranych czynników o charakterze społeczno-ekonomicznym na różnorodne zachowania zdrowotne podejmowane przez młodych ludzi. Wśród analizowanych determinantów znalazły się: grupa rówieśnicza, środowisko szkolne, rodzina, status socjoekonomiczny oraz społeczność. Oprócz ostatniej wymienione zmienne postrzega się jako najbardziej kluczowe z punktu widzenia zdrowia młodzieży (Lazzeri et al. 2014). Należy zaznaczyć, że autorzy publikacji dokonywali analizy wpływu tych uwarunkowań w kontekście ogólnoświatowych zmian społecznych, gospodarczych i kulturalnych, które ukształtowały warunki, w jakich obecnie współczesna młodzież podejmuje zachowania związane ze zdrowiem. Niektóre artykuły określały kierunek związków pomiędzy badanymi determinantami i zachowaniami w odniesieniu do ogólnoświatowego problemu zdrowotnego, jakim jest występowanie nadwagi i otyłości u młodych osób wraz z jego licznymi skutkami psychosomatycznymi i ekonomicznymi (Thibault et al. 2009; Ferreira et al. 2006; Haug et al. 2006; Gordon-Larsen et al. 2000).

Uzyskane wyniki pozwoliły na potwierdzenie istnienia relacji zachodzących pomiędzy wybranymi czynnikami społeczno-ekonomicznymi a podejmowaniem konkretnych zachowań związanych ze zdrowiem oraz określenie stopnia tego oddziaływania. Odnotowano, że wysoki SES wykazał pozytywną relację z m.in. wzrostem średniego czasu poświęcanego na aktywność fizyczną (Thibault et al. 2009), wyższą aktywnością fizyczną (Ferreira et al. 2006) i większym spożyciem 
owoców i śniadań (Haug et al. 2006). Powiązany był także z mniejszym spożyciem słodkich napojów i mniejszą częstością występowania otyłości (Haug et al. 2006). W świetle powyższych wyników można wnioskować, że w rodzinach o wyższym SES istnieje większa świadomość znaczenia aktywności fizycznej i prawidłowego odżywiania, dostępne są środki finansowe i czas na uczestniczenie w zajęciach ruchowych. Z kolei niski SES przekładał się na większą skłonność do podejmowania zachowań szkodzących zdrowiu, w tym: palenia papierosów i stosowania narkotyków, negatywnych nawyków żywieniowych oraz zachowań sedenteryjnych. Zauważono również, że zwiększał ryzyko otyłości. Uzyskane wyniki wykazują podobieństwo z raportem HBSC 2001/2002 podkreślającym wpływ niskiego SES na zwiększone ryzyko podejmowania zachowań szkodliwych (głównie palenia papierosów, picia alkoholu i przejadania się). Według tego dokumentu jedną z przyczyn takiej zależności może być stres wynikający z niższego statusu społecznego (Currie et al. 2004).

Analiza wpływu środowiska szkolnego wykazała, że o skłonności do podejmowania zachowań zdrowotnych decydowały w największym stopniu: poczucie przynależności do szkoły, jej wspierający charakter oraz relacje rodziców i dzieci ze szkołą. Postrzeganie szkoły jako środowiska wspierającego było związane z większą częstością podejmowania zachowań sprzyjających zdrowiu oraz mniejszą częstością palenia papierosów i zgłaszania skarg związanych ze zdrowiem (Currie et al. 2012). Z kolei w relacjach szkolnych i wysokim poczuciu przynależności do środowiska szkolnego dostrzeżono funkcję ochronną przed zachowaniami ryzykownymi (Viner et al. 2012; Brooks et al. 2012). Nie bez znaczenia okazały się silne relacje pomiędzy rodzicami, dzieci i szkołą, których rezultatem były pozytywne skutki zdrowotne (Viner et al. 2012).

Jeśli chodzi o możliwości oddziaływania na zdrowie młodych ludzi, szczególna uwaga należy się grupie rówieśniczej. Według uzyskanych wyników czynnik ten wykazał związki głównie z zachowaniami szkodliwymi: spożywaniem niedozwolonych substancji (Lazzeri et al. 2014; Farmer, Hanratty 2012; Sawyer et al. 2012) i siedzącym trybem życia (Lazzeri et al. 2014). Ponadto zauważono, że wspólne eksperymentowanie $z$ alkoholem jest niekiedy postrzegane przez młodych ludzi jako warunek socjalizacji i sposób na spędzanie czasu wolnego (Jackson et al. 2012). Aczkolwiek w literaturze przedmiotu dostrzega się dwukierunkowy wpływ rówieśników na podejmowanie zachowań zdrowotnych, w zależności od rodzaju grupy i środowiska (Viner et al. 2012). Opisując oddziaływanie grupy rówieśniczej, warto wspomnieć o rozszerzeniu dotychczasowego znaczenia tego terminu wynikającym z rozwoju mediów społecznościowych (Sawyer et al. 2012).

W przypadku rodziny będącej ostatnim analizowanym uwarunkowaniem należy podkreślić jej istotną rolę w kształtowaniu nawyku aktywności fizycznej u dzieci. Aktywność ruchowa rodziców była powiązana z aktywnością fizyczną (Raudsepp, Viira 2000) i mniejszą częstością zajęć sedenteryjnych (Thibault et al. 2009) dzieci. Co więcej, wykazano związek między nadwagą rodziców i dzieci (Thibault et al. 2009). Ważne dla redukcji zachowań szkodliwych dla zdrowia okazały się dobre relacje z rodzicami, które przełożyły się bezpośrednio na niższą skłonność do regularnego stosowania szkodliwych substancji (Farmer, Hanratty 
2012). Dodatkowo należy zauważyć, że rodzice poprzez osobisty przykład oraz decyzyjność w zakresie organizowania czasu wolnego dziecka mogą wpłynąć na jego mniejsze zaangażowanie w zachowania szkodzące zdrowiu (Viner et al. 2012; Brooks et al. 2012).

Analizując powyższe dane pod kątem tworzenia skutecznych programów promocji zdrowia w rzeczywistości szkolnej, można wnioskować, że szkoła nie jest w stanie poprawić niskiego SES rodzin, zmniejszyć wpływu grupy rówieśniczej lub społeczności na jednostkę. Nie zawsze jest w stanie zmienić nawyki zdrowotne rodziców i uświadomić im ich odpowiedzialność za zdrowie dziecka. W dobie rozwoju nowych mediów nie jest także w stanie wpłynąć na dostęp młodzieży do różnych informacji z całego świata. Jednakże poprzez obowiązkowe lekcje wychowania fizycznego zawierające wymagania szczegółowe z edukacji zdrowotnej może zredukować działania niepożądane oraz rozwinąć zachowania prozdrowotne (w szczególności aktywność ruchową). Wydaje się to kluczowe w świetle badań wskazujących, że lekcje wychowania fizycznego nierzadko są jedyną okazją młodzieży do podjęcia aktywności fizycznej (Gordon-Larsen et al. 2000).

Podsumowując wyniki badań, należy nadmienić, że autorzy wskazywali na istnienie różnic międzypłciowych w zaangażowaniu młodych ludzi w zachowania wspierające osiągnięcie pełnego potencjału zdrowotnego oraz ryzykowne dla zdrowia. Opisując zachowania sprzyjające zdrowiu, na korzyść chłopców przemawiała m.in. większa skłonność do podejmowania aktywności fizycznej (Currie et al. 2012; Gordon-Larsen et al. 2000), z kolei u dziewcząt dostrzeżono większą tendencję do spożywania owoców oraz unikania słodkich napojów (Currie et al. 2012). Biorąc pod uwagę różnice płciowe, w obrębie działań niekorzystnych dla zdrowia u chłopców wykazano większą podatność na alkohol, marihuanę, uczestnictwo w bójkach (Currie et al. 2012; Farmer, Hanratty 2012), narkotyki (Farmer, Hanratty 2012), słodkie napoje (Currie et al. 2012; Haug et al. 2006 ), kontuzje (Viner et al. 2012), spędzanie większej ilości czasu na grach video i korzystaniu z komputera (Thibault et al. 2009). Zauważano u nich także częstsze występowanie otyłości (Viner et al. 2012, Thibault et al. 2009; Haug et al. 2006). W przypadku dziewcząt wykazano zwiększoną tendencję do m.in.: niskiej aktywności ruchowej obejmującej wysiłek fizyczny podejmowany w szkole, w czasie wolnym, w ramach klubów sportowych i centrów rekreacji (Thibault et al. 2009; Gordon-Larsen et al. 2000), większego spadku aktywności fizycznej wraz z wiekiem (Haug et al. 2006) i nieregularnego spożywania śniadań (Currie et al. 2012).

\section{Wnioski}

Na podstawie uzyskanych wyników można sformułować konkluzje:

1. Niski SES jest związany z niekorzystnymi nawykami żywieniowymi, sedenterią, niską aktywnością fizyczną i wyższą zapadalnością na choroby.

2. Szkoła jest właściwym miejscem eliminacji nierówności w zakresie zdrowia młodych ludzi (poprzez dostęp do osób z rodzin zarówno o wysokim, jak i niskim SES oraz nauczycieli mogących odgrywać rolę autorytetów). 
3. Szkoła powinna dostrzec swoje możliwości w kształtowaniu zachowań zdrowotnych, budować pozytywne relacje z dziećmi i rodzicami oraz wspierać ich merytorycznie poprzez np. organizowanie spotkań edukacyjnych.

4. Środowisko szkolne i rodzice powinni wykorzystać zaangażowanie młodych ludzi w nowoczesne technologie komunikacyjno-informacyjne do promowania właściwych zachowań zdrowotnych. Winni też mieć na uwadze szkodliwe skutki tego zjawiska (np. przyjęcie negatywnych zachodnich wzorców konsumpcji i zdeprawowanych grup młodzieżowych oraz wzrost liczebności i znaczenia grupy rówieśniczej).

5. Warto, aby rodzice brali udział w organizowaniu czasu wolnego swoich dzieci, pozwalali im na dzielenie się problemami i dawali dobry przykład w zakresie zachowań zdrowotnych.

6. Zaleca się, aby nauczyciele wychowania fizycznego uczynili użytek z potencjału tego przedmiotu w kształtowaniu zachowań prozdrowotnych i szansy będącej wynikiem umieszczenia treści edukacji zdrowonej w nowej podstawie programowej. Wysiłki edukacyjne powinny być w szczególności ukierunkowane na zmniejszenie lub prewencję sedenteryjnego trybu życia, palenia papierosów i spożywania niedozwolonych substancji.

7. Wskazuje się na różnice międzypłciowe w adaptacji zachowań związanych ze zdrowiem oraz w zakresie wzorców zdrowotnych w zależności od kontekstu lokalnego.

\section{Literatura}

Brooks F.M., Magnusson J., Spencer N., Morgan A., Adolescent multiple risk behaviour: an asset approach to the role of family, school and community, „Journal of Public Health” 2012, 34(S1), s. $48-56$.

Cazuza de Farias Júnior J., Mendonça G., Florindo A.A., Gomes de Barros M.V., Reliability and validity of a physical activity social support assessment scale in adolescents - ASAFA Scale, „Revista Brasileira de Epidemiologia" 2014, 17(2), s. 355-370.

Currie C., Zanotti C., Morgan A., Currie D., Looze M., Roberts C., Samdal O., Smith O., Barnekow V., Social determinants of health and well-being among young people. Key findings from the Health Behaviour in School-aged Children (HBSC) study: international report from the 2009/2010 survey, WHO Regional Office for Europe, Copenhagen 2012.

Currie C., Roberts C., Morgan A., Smith R., Settertobulte W., Samdal O., Barnekow Rasmussen V., Young people's health in context. Health Behaviour in School-aged Children (HBSC) study: international report from the 2001/2002 survey, „Health Policy for Children and Adolescents” 2004, 4, s. 13.

Farmer S., Hanratty B., The relationship between subjective wellbeing, low income and substance use among schoolchildren in the north west of England: a cross-sectional study, „Journal of Public Health" 2012, 34(4), s. 512-522.

Ferreira I., van der Horst K., Wendel-Vos W., Kremers S., van Lenthe F.J., Brug J., Environmental correlates of physical activity in youth - a review and update, The International Association for the Study of Obesity. 8 (Obesity reviews), 2006, s. 129-154.

Gordon-Larsen P., McMurray R.G., Popkin B.M., Determinants of Adolescent Physical Activity and Inactivity Patterns, „Pediatrics” 2000, 105(6), s. e83. 
Hanson M.D., Chen E., Socioeconomic Status and Health Behaviors in Adolescence: A Review of the Literature, „Journal of Behavioral Medicine” 2007, 30, s. 263-285.

Haug E., Samdal O., Morgan A., Ravens-Sieberer U., Currie C., Overweight in school-aged children in 35 countries: associations witheating habits, physical activity, socioeconomic status and perceived health, [w:] Addressing the socioeconomic determinants of healthy eating habits and physical activity levels among adolescents, WHO Europe, 2006, s. 14-21.

Jackson C.A., Henderson M., Frank J.W., Haw S.J., An overview of prevention of multiple risk behaviour in adolescence and young adulthood, „Journal of Public Health” 2012, 34(S1), s. 31-40.

Lazzeri G., Azzolini E., Pammolli A., Simi R., Meoni V., Giacchi M.V., Factors associated with unhealthy behaviours and health outcomes: a cross-sectional study among tuscan adolescents (Italy), "International Journal for Equity in Health” 2014, 13(83).

Raudsepp L., Viira R., Sociocultural Correlates of Physical Activity in Adolescents, „Pediatric Exercise Science" 2000, 12, s. 51-60.

Resnick M.D., Catalano R.F., Sawyer S.M., Viner R., Patton G.C., Seizing the opportunities of adolescent health, „The Lancet” 2012, 379, s. 1564-1567.

Sawyer S.M., Afifi R.A., Bearinger L.H., Blakemore S.J., Dick B., Ezeh A.C., Patton G.C., Adolescence: a foundation for future health, „The Lancet” 2012, 379, s. 1630-1640.

Thibault H., Contrand B., Saubusse E., Baine M., Maurice-Tison S., Risk factors for overweight and obesity in French adolescents: Physical activity, sedentary behavior and parental characteristics, „Nutrition” 2009, 7, s. 192-200.

Viner R.M., Ozer E.M., Denny S., Marmot M., Resnick M., Fatusi A., Currie C., Adolescence and the social determinants of health, „The Lancet” 2012, 379, s. 1641-1652. 